\title{
AGE OF BLACK COLOURED LAMINAE WITHIN SPELEOTHEMS FROM DOMICA CAVE AND ITS SIGNIFICANCE FOR DATING OF PREHISTORIC HUMAN SETTLEMENT
}

\author{
MICHAL GRADZIŃSKI ${ }^{1}$, HELENA HERCMAN ${ }^{2}$, MAREK NOWAK ${ }^{3}$ and PAVEL BELLA ${ }^{4}$ \\ ${ }^{1}$ Institute of Geological Sciences, Jagiellonian University, \\ Oleandry 2a, 30-063 Kraków, Poland \\ ${ }^{2}$ Institute of Geological Sciences, Polish Academy of Sciences, \\ Twarda 51/55, 00-818 Warszawa, Poland \\ ${ }^{3}$ Institute of Archaeology, Jagiellonian University, \\ Gotębia 11, 31-007 Kraków, Poland \\ ${ }^{4}$ Administration of Slovak Caves, \\ Hodžova 11, 03101 Liptovský Mikuláš, Slovakia
}

\begin{abstract}
The paper deals with the black coloured laminae which occur within speleothems in Domica cave (Slovakia). The laminae are composed of non completely carbonized organic compounds and charcoal particles. The components were formed during combustion of plant material, mainly wood, inside the cave. Thus, they are a by-product of human activity inside the cave. The radiocarbon ages of organic fraction of these laminae fall between 6460 and $6640 \mathrm{cal} \mathrm{BP}$ and 7160 and $7330 \mathrm{cal}$ BP. These dates indicate that the origin of the laminae is connected with two episodes of prehistoric occupation of the cave. The first one should be related either to later part of Gemer Linear Pottery or to early Bükk culture populations. The second episode refers to the youngest phase of human occupation in Domica cave reflecting the last period of Bükk populations' existence in the Slovak Karst.
\end{abstract}

Keywords: speloethems, Neolithic, Bükk culture, Domica cave, Slovak Karst.

\section{INTRODUCTION}

The caves all over the world were frequently used by prehistoric humans as, more or less, periodical shelters. Hence, human activity is often recorded within caves. Archaeological materials such as different tools or pottery are commonly found within cave clastic deposits. The most spectacular traces of human activity are wall paintings. Moreover, the black coloured laminae inside speleothems are also genetically connected with prehistoric men's activity in caves. The laminae are dyed by small organic compounds originated during combustion of plant material within caves. Gradziński et al. (2003) described such laminae in stalagmites and flowstones from the caves of southern Poland. Similar origin was ascribed to black material found on the surface of cave walls in

Corresponding author: M. Gradziński

e-mail: gradzinm@ing.uj.edu.pl

ISSN 1897-1695 (online), 1733-8387 (print) (C) 2007 GADAM Centre,

Institute of Physics, Silesian University of Technology.

All rights reserved.
United States (Bennington et al., 1962, Watson, 1966; Hill, 1982; Steelman et al., 2002). The spectacular black coloured laminae were detected in speleothems from Domica cave (Roth, 1948; Petránek and Pouba, 1951; Gradziński et al., 2002), which is famous for human occupation during Neolithic period representing especially the Bükk culture (Bárta, 1965; Lichardus, 1968). Similar laminae were also found in other caves of the Slovak Karst region (Bárta, 1984).

Several attempts have been made to estimate the age of the prehistoric human activity in caves. The ${ }^{14} \mathrm{C}$ method has been commonly used by dating different materials, such as human remains, animal bones and charcoal particles. In the recent years the application of accelerator mass spectrometry (AMS) method has allowed measuring of ${ }^{14} \mathrm{C}$ concentration in the relatively small samples, which in turn enabled dating such objects as pigments used for cave paintings (Valladas et al., 2001). This paper presents the application of AMS 
method to date organic compounds occurring within the black coloured laminae in speleothems from Domica cave. The significance of the obtained dates for chronology of Slovak Neolithic is discussed as well since there have been reported only a few dates connected with the Bükk culture so far (Vogel and Waterbolk, 1964; Bárta, 1965; Breuning, 1987).

\section{SPELEOLOGICAL SETTING}

Domica cave is located in the Slovak Karst, near the Slovak-Hungarian border (Fig. 1). The name Domica refers to the Slovak part of a big cave with total length of about $25 \mathrm{~km}$, whose Hungarian part is named Baradla. Domica cave is more than $5000 \mathrm{~m}$ long (Droppa, 1970). The cave comprises several spacious rooms and passages. It is also famous for numerous giant speleothems. A perennial underground stream, called Styx, flows through the lowermost part of the cave.

Domica cave was settled by prehistoric humans in Upper Palaeolithic and mainly during Neolithic (Bárta, 1965; Lichardus, 1968 and 1974; Soják, 2005). Afterwards the entrance was blocked by a colluvial deposits and the cave was not accessible until the twenties of the last century. There are four main periods of Neolithic settlement. According to Lichardus (1974), the first one embraces black painted pottery of so called Domica type (Domica Ia), painted and polished pottery with possibly proto-Vinča features (Domica Ib), as well as Gemer Linear Pottery (Domica Ic). Most probably, all these pottery groups belong to the middle and late Eastern Linear Pottery culture (Pavúk and Šiška, 1980; Šiška 1989). The second, third and fourth period should be connected with the Bükk culture (Bárta, 1965; Lichardus, 1968 and 1974; Titov, 1980; Soják, 2005). Many archaeological materials were found in Domica cave, which comprises more than 45000 fragments of pottery as well as numerous lithic and bone artefacts. More than $85 \%$ of archaeological remains belong to the Bükk culture and thus the cave is one of the most important sites of this culture. Neolithic man settled the cave several hundred years. It is Lichardus' (1968) belief that the cave was utilized periodically, probably during winter seasons, as a kind of station for pasturing activity. Moreover, in Bárta's (1965) and Lichardus' (1968) opinion, the cave was also a place of subterranean exploitation of fine grained clastic deposits for producing pottery, a source of water, as well as, a holy place. The distribution of archaeological remains and foot traces indicate that the zone of human activity in the cave included also its deep, completely dark sections, as far as a few hundred metres away from the entrance.

\section{MATERIALS AND METHODS}

The laminae were found in several small stalagmites as well as in the flowstone covers situated in the chamber called Sieň odvahy (Hall of Courage) and the lower part of the passage called Panenská chodba (Virgin Passage) (Fig. 1). It is noteworthy that in the chamber Sieñ odvahy there is a vessel belonging to Bükk culture partly coated with thin flowstone cover.

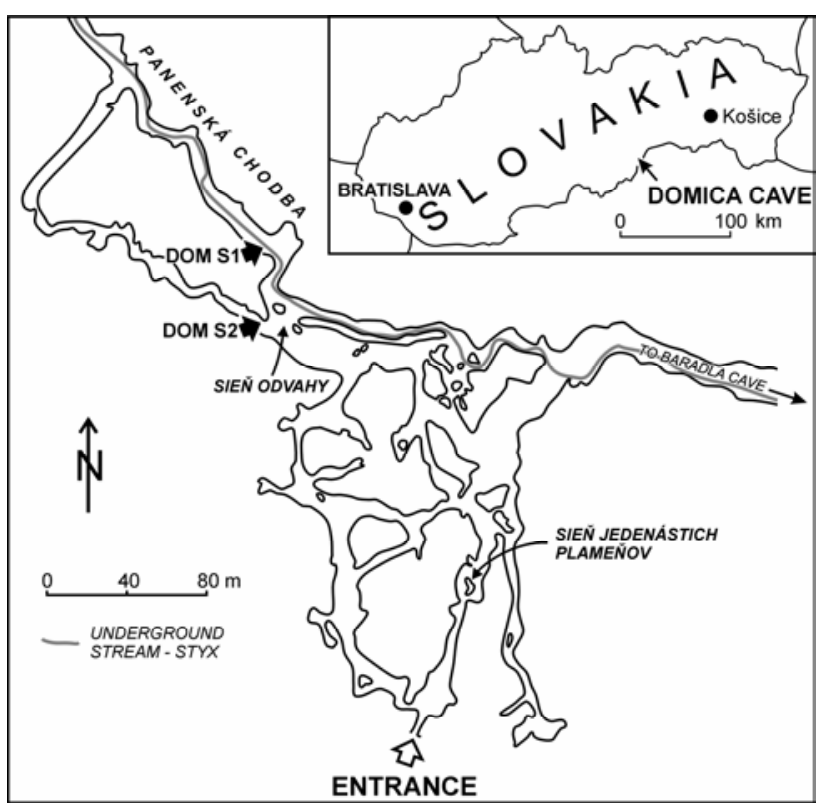

Fig. 1. Location of Domica cave and map of the central part of the cave (after Droppa 1970) showing position of sampling places.

Polished slabs of speleothems were studied. The observations were then extended through thin section analyses. The black coloured laminae were cut out of the samples, then washed in distilled water and dissolved in $2 \%$ $\mathrm{HCl}$. The dissolved residuum were examined under scanning electron microscope (SEM) JEOL 5410, while their chemical composition was determined using an analyser Voyager 3100 (EDS) connected to the microscope.

Two ca. $1 \mathrm{~cm}$ thick flowstone samples with black coloured laminae were chosen for dating. The sample labelled as Dom S1 derived from the passage Panenská chodba while the sample labelled as Dom S2 from the upper part of the chamber Sien odvahy (Fig. 1). Radiocarbon dating have been performed in Poznań Radiocarbon Laboratory using AMS technique (Goslar et al., 2004). The ${ }^{14} \mathrm{C}$ concentration of the samples was measured in the spectrometer "Compact Carbon AMS" produced by National Electrostatics Corporation, USA. Standard sample pretreatment procedure described by Czernik and Goslar (2001) was used after preliminary separation of black lamiae. At the $\mathrm{NaOH}$ treatment all the sample have been dissolved and radiocarbon dating have been performed on $\mathrm{NaOH}$ soluble fraction. Quoted errors are 1 standard deviation and the age is conventional radiocarbon age. Radiocarbon dates obtained in this work as well as radiocarbon dates of charcoal from Domica Cave published earlier (Vogel and Waterbolk, 1964; Bárta, 1965; Breuning, 1987) have been calibrated using OxCal v. 3.10 (Bronk Ramsey, 1995 and 2001) with calibration curve for atmospheric data from Reimer et al. (2004).

\section{RESULTS}

\section{Black coloured laminae}

Macroscopically, the black coloured laminae are less than $0.8 \mathrm{~cm}$ thick (Fig. 2). Commonly, one macroscopi- 
cally visible lamina is composed of a few intensely coloured laminae, which can be observed under the microscope. The laminae in question interlayer with laminae built of small calcite crystals (Fig. 3). The opaque and semiopaque components forming dark coloured laminae occur on uncorroded calcite crystals and, seldom, on

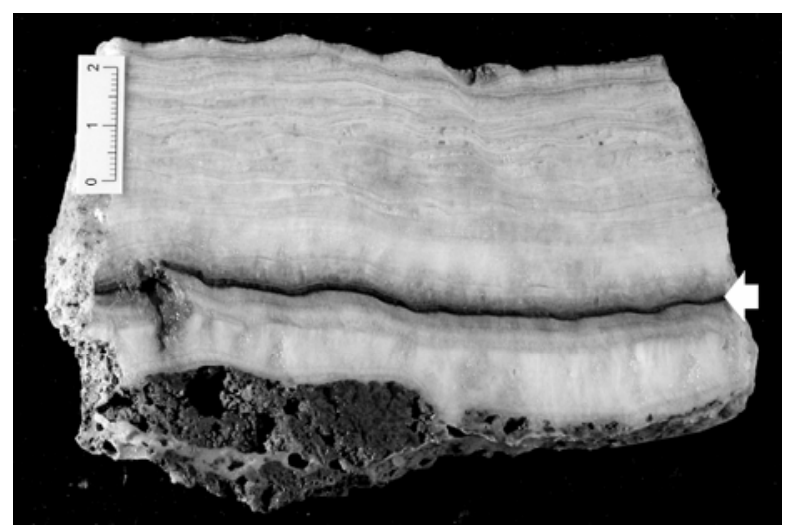

Fig. 2. Polished slab of flowstone from Panenská chodba, crosssection, arrow indicate black coloured laminae providing sample Dom $\mathrm{S1}$; scale bar $2 \mathrm{~cm}$.

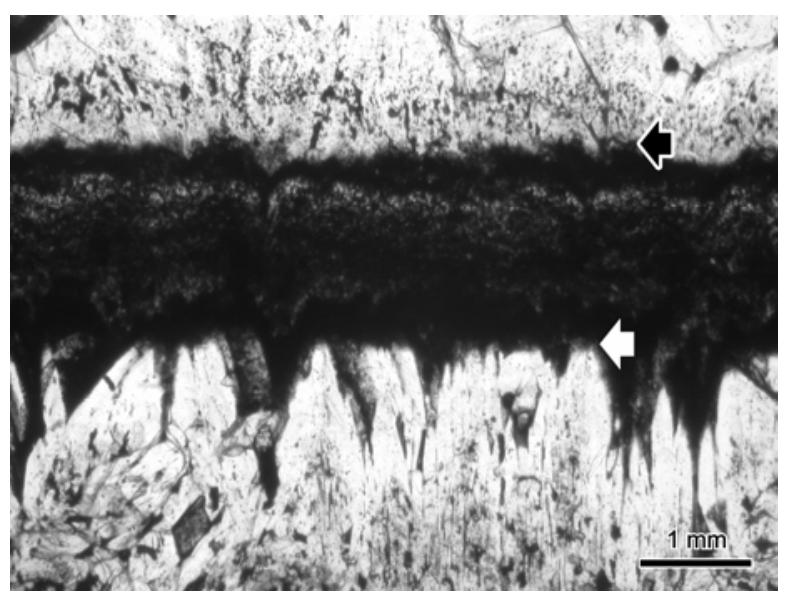

Fig. 3. Black coloured laminae microscopic view; white arrow shows mixture of opaque and semiopaque components wrapping terminations of older crystals, black arrow shows younger crystals growing competitively on black coloured laminae.

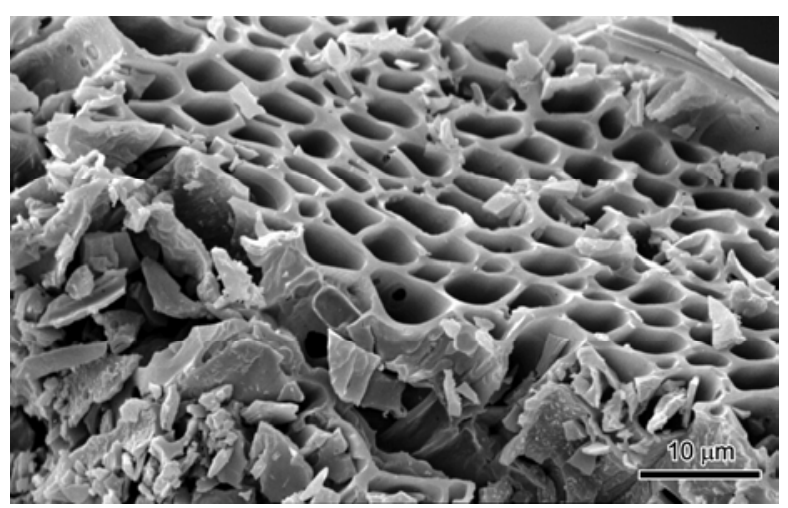

Fig. 4. Ultrastructure of charcoal particle, homogenization of cell wall structure is visible. corrosional surfaces (Gradziński et al., 2002). In the former case they wrap the crystal terminations with the layer so thick that younger crystals start to grow competitively (Fig. 3; see González et al., 1992).

The dark coloured laminae comprise semiopaque components and opaque particles. The latter possess angular shape and jet black colour. They differ in size and shape. The smallest are only some micrometers long, while the largest are up to a few millimetres long. The shape of opaque particles is commonly isometric; however, some particles display elongate shape. The opaque particles are non-fluorescent. All the above characteristics prove that particles in question are charcoal fragments (Patterson et al., 1987; Jones and Chaloner, 1991). The above statement is confirmed by the observation of their internal structures by means of SEM (Fig. 4). The majority of the particles is characterized by homogenization of cell wall ultrastructure (Sander and Gee, 1990; Jones and Chaloner, 1991; Vaughan and Nicols, 1995). Some of them are destroyed by cracking, which leads to disintegration of larger particles. The processes of homogenization are due to combustion of wood in the temperature of about $400^{\circ} \mathrm{C}$ (Jones and Chaloner, 1991; Vaughan and Nicols, 1995).

The semiopaque components are intensively brown in transparent light and display yellow-brown UV fluorescence. They are hydrophobic but soluble in $\mathrm{NaOH}$ solution. It indicates that they are composed of non carbonized organic compounds (Teichmüller and Wolf, 1977; Dravies and Yurevicz, 1985). These components occur mixed together with charcoal particles.

\section{Radiocarbon age of black coloured laminae}

Obtained results of radiocarbon dating are presented in Table 1. The age is conventional radiocarbon age. Calibration results are presented in Table 1 and Fig. 5. Organic fraction constituting soot from Dom S1 (Poz2444) sample was deposited between 6460 and 6640 cal BP, while from Dom S2 (Poz-2442) sample between 7160 and 7330 cal BP. The age of both samples are significantly different. Hence time span between human occupations indicated by these samples is minimum ca. 500 years.

\section{DISCUSSION}

\section{Origin of black coloured laminae}

The black coloured laminae are dyed by soot composed of charcoal particles and non completely carbon-

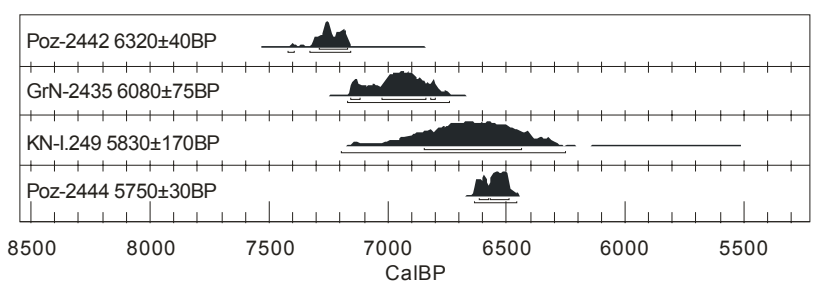

Fig. 5. Comparison of new and previous dating results from Domica cave presented as calibrated dates. 
Table 1. Dating and calibration results.

\begin{tabular}{|c|c|c|c|c|c|}
\hline \multirow{2}{*}{$\begin{array}{c}\text { Sample, } \\
\text { laboratory } \\
\text { number }\end{array}$} & \multirow[t]{2}{*}{$\begin{array}{l}{ }^{14} \mathrm{C} \text { age } \\
\text { (yr BP) }\end{array}$} & \multicolumn{2}{|c|}{$\begin{array}{c}68.2 \% \text { conf. } \\
\text { intervals }\end{array}$} & \multicolumn{2}{|c|}{$\begin{array}{c}95.4 \% \text { conf. } \\
\text { intervals }\end{array}$} \\
\hline & & $\begin{array}{l}\text { Cal. age } \\
\text { range } \\
\text { (yr BP) }\end{array}$ & $\begin{array}{c}\text { Prob. } \\
(\%)\end{array}$ & $\begin{array}{l}\text { Cal. age } \\
\text { range } \\
\text { (yr BP) }\end{array}$ & $\begin{array}{c}\text { Prob. } \\
(\%)\end{array}$ \\
\hline $\begin{array}{c}\text { Dom S1 } \\
\text { Poz-2444 }\end{array}$ & $5750 \pm 30$ & $\begin{array}{l}6620-6580 \\
6570-6490\end{array}$ & $\begin{array}{l}14.4 \\
53.8 \\
\end{array}$ & 460 & 95.4 \\
\hline $\begin{array}{c}\text { Dom S2 } \\
\text { Poz-2442 }\end{array}$ & $6320 \pm 40$ & $7290-7170$ & 68.2 & $7330-7160$ & 95.4 \\
\hline $\begin{array}{l}\text { Kečovo* } \\
\text { GrN-2435 }\end{array}$ & 608 & $\begin{array}{l}7160-7120 \\
7030-6830 \\
6820-6790\end{array}$ & $\begin{array}{r}7.5 \\
56.7 \\
4.0\end{array}$ & $7170-6750$ & 95.4 \\
\hline KN-I.249** & $5830 \pm 170$ & $6850-6440$ & 68.2 & $7200-6250$ & 95.4 \\
\hline
\end{tabular}

* sample delivered by J Bárta and cited by Vogel and Waterbolk (1964)

** sample delivered by J Lichardus and cited by Breuning (1987)

ized organic compounds. The soot is cemented by calcium carbonate. It proves that the formation of the laminae was genetically connected with combustion of plant tissue. The occurrence of laminae within speleothems in the deep, remote from the entrance zone part of the cave shows that dying components could not been transported into the cave by wind action (see discussion in Gradziński et al., 2003). The lack of any other, except dying components, non-carbonate particles excludes the possibility of their transport from soil by percolating water. Moreover, the hydrophobic character of the components in question further denies the possibility of their transport by water from soil overlying the cave (see discussion in Fezzey and Armitage, 2006). Hence, the dying components originated inside the caves as a by-product of human activity. They were spread around owing to convection flow of hot air (Clark, 1988) and subsequently were trapped on the wet surface of speleothems. Finally, they were cemented by subsequently growing calcite and together formed black coloured laminae. In the light of the above presented origin of laminae in question they are a good indicator of human inhabitation of Domica cave, which confirms earlier opinions by Roth (1948), Petránek and Pouba (1951) as well as Gradziński et al. (2002). Bearing this in mind, the age of the laminae can be treated as the age of human occupation of the cave.

\section{Radiocarbon age of black coloured laminae}

Radiocarbon dating have been performed on $\mathrm{NaOH}$ soluble fraction. Later contamination by younger carbon for this fraction is of high risk, especially for materials not isolated from water circulation or human impact. Soot constituting the Dom S1 (Poz-2444) and Dom S2 (Poz2442) samples were well isolated from surroundings by massive calcite layers of flowstones and, moreover, it comprises not only $\mathrm{NaOH}$ soluble fraction but also small charcoal particles. In this situation probability of younger contamination is rather low and can be neglected.

The age of charcoals found by Bárta (1965) and dated in Groningen laboratory (GrN-2435; Vogel and Waterbolk, 1964) is exactly between the ages of "new" samples (Fig. 5). The age of younger sample (Dom S1) overlaps with the age of charcoals dated in Köln laboratory and delivered there by J. Lichardus (KN-I.249), however the latter date spreads over the longer time span due to significant standard deviation. It is worth mentioning that the samples GrN-2435 and KN-I.249 were dated using conventional measurement technique, which means that mass of the samples are several times bigger than samples for AMS measurements.

From the theoretical point of view three possible scenarios can explain this dating results. First scenario is that there were at least two phases of human occupation in Domica cave. The first is indicated by Dom S1 sample, and the second by Dom S2 and possibly J. Lichardus' (KN-I.249) samples. The relatively huge sample (labeled Kečovo) delivered by J. Bárta for dating could have been a mixture of two generation of charcoal connected with these two phases. If we assume simple mixing of Dom S1 and Dom S2 samples for obtaining age equal $6080 \mathrm{yr}$ BP we need almost proportional mixing ( $40 \%$ of Dom S1 and $60 \%$ of Dom S2 samples material).

The second scenario assumes that there was one period of human occupation in Domica cave. That period was long but not necessary continuous. The date GrN2435, obtained for a big sample has yielded us middle age of this period. Precise AMS dating based on small samples (Dom S1 and Dom S2) has given information about age of earlier and later episodes of cave penetration representing the same long period of human activity in the cave. Taking this into account one may assume that prehistoric man penetrate different part of the cave during different episodes.

The third scenario presumes that all four dates are the record of independent periods of human habitation in Domica cave separated by substantial settlement hiatuses.

On account of occurrence of all Bükk culture pottery styles (Lichardus, 1968 and 1974) we are of the opinion that the second scenario is the most probable, at least with reference to the occupation of the cave by groups of this archeological unit.

\section{Archaeological context}

The radiocarbon dating of black coloured laminae from Domica cave can add a new dimension to the discussion on the chronology of the Bükk culture in southeastern Slovakia. However, the prehistoric interpretation of the two dates obtained from black coloured laminae in speleothems evokes some difficulties due to three main reasons.

Firstly, a detailed archaeological monograph of Domica cave has not been published to date. Consequently, we have no meticulous information referring to the distribution of the phases of human occupation in all parts of the cave. Similarly, our understanding of stratigraphical arrangement of cultural layers in the cave is far from being exhaustive. For instance, the stratigraphical context of "old" date GrN-2435 is obscure; hence, we are not able to correlate the date with any of human settlement stages directly. The only piece of information available says that the place of sampling was situated in eastern part of Sieň jednástich plameňov (Chamber of Eleven Flames; Bárta, 1965). Another ${ }^{14} \mathrm{C}$ date from Domica cave is reported by Breuning (1987). Similarly, there are no data on the stratigraphical and archaeological context 
of the charcoal sample delivered by J. Lichardus and dated at 5830 $\pm 170 \mathrm{yr}$ BP (KN-I.249) (Breuning, 1987).

Secondly, although existing descriptions and studies are very general, they nevertheless suggest that the two dates under discussion come from those parts of the cave (Panenská chodba and Sieň odvachi) which were not intensively used. According to Bárta (1965) and Lichardus (1968) only stray finds of Neolithic age (inter alia the Bükk culture) were found in both places. We may suppose that no traces of cultural layer were identified there. Therefore, we have no direct premises for establishing the relationship between the dates and any of the settlement phases discerned by Lichardus (1968 and 1974) for Domica cave.

Thirdly, the amount of radiometric dates referring to the Bükk culture (which makes the prevailing part of archaeological material in Domica cave) is very limited to date. There are only three dates from Bükk contexts obtained in Eastern Slovakia: i) two aforementioned "old" dates from Domica, and ii) the unpublished date from the site of Slavkovce (Michalovce region) [Gd10468: $6110 \pm 130$ yr BP; excavations by M. Vizdal]. Radiometric data from Hungary that can be found in literature are imprecise. For example, in the paper by Hertelendi et al. (1995) 30 dates have been mentioned as referring to the horizon Szakálhat-Esztár-Bükk. However, there is no information which part of this set refers to the Bükk culture proper. We may ascertain that the majority of these dates belong to the Szakálhat group (see Hertelendi and Horváth, 1992). In effect, the absolute chronology of the Bükk culture has been worked out mainly on the basis of comparisons with absolute chronology of other Neolithic units.

If we take into account previous works (Lichardus, 1974; Kalicz and Makkay, 1977; Pavúk and Šiška, 1980; Šiška, 1989; Hertelendi and Horváth, 1992; Raczky et al., 1994 and 2002; Hertelendi et al., 1995 and 1998), it seems quite possible that the formation process of the Bükk culture (in the Slovak Karst?) was contemporaneous to the late phases of Eastern Linear Pottery culture (AVK) groups: Tiszadob, Raškovce and Gemer Linear Pottery as well as to the late Notenkopf phase of the Linear Band Pottery culture (LBK). Therefore, we should date this process to $c a$. 7250/7150 cal BP. The further development of the culture under consideration is connected with significant enlargement of its territorial extent. In effect, Bükk culture embraced most areas of Eastern Slovakia and western section of North-Eastern Hungary (Kalicz and Makkay, 1977; Šiška, 1979 and 1998; Titov, 1980; Vizdal, 1998; Soják, 2000). Its existence is considered as roughly parallel to the Szakálhat group and partly to Esztár group (both belong to AVK sensu largo), Želiezovce group (late LBK), and phase B of Vinča culture. Consequently, the absolute chronology of the Bükk culture should cover the period between $c a$. 7250/7150 and $6750 \mathrm{cal} \mathrm{BP.}$

The older of the two "new" dates points at the very beginning of the foregoing chronological span of this archaeological unit. On the other hand, we should bear in mind that its probability distribution after calibration spreads over the period ca. 200 years (two sigma probability range) as well as that early Bükk and late AVK groups were contemporaneous. Therefore, it is our belief that two alternatives should be considered in regard to prehistoric interpretation. The date can be a reflection of human activity of either one of the later episodes of Gemer Linear Pottery or early (the earliest?) Bükk culture populations. In case of the former alternative, stages $\mathrm{Ib}$ or Ic of Domica settlement should be considered; in case of the latter one, phases IIa or IIb can be mentioned. Unfortunately, the present state of research makes the evaluation of probability of these options impossible.

In theory, the second date seems to be slightly late if we assess it from the Bükk chronology perspective. However, it must be emphasized again that the knowledge about Bükk chronology is based on circuitous data. Moreover, the disappearance of the Bükk culture is an extremely complicating question (Šiška, 1986 and 1995) due to lack of Late Neolithic settlement in every single area of the Bükk settlement (except Eastern Slovak Lowland - Šiška, 1979). In spite of some assumptions (Lichardus, 1968 and 1974; Šiška, 1995), traces of Bükk tradition have not been discovered within Late Neolithic groupings in other territories of the Carpathian Basin. Essentially, there are no hard premises for exact dating of the sudden (as they suppose) vanishing of the Bükk culture. Thus, we think that the date Poz-2444 can reflect the youngest (IV) phase of the human occupation in Domica Cave. Perhaps it should be regarded as an indication of the last period of Bükk populations' existence in the Slovak Karst, in the second quarter of the seventh millennium BP.

\section{CONCLUSIONS}

1) Black coloured laminae occurring in speleothems in Domica cave are dyed due to non carbonized organic compounds and charcoal particles developed during wood combustion inside the cave.

2) The laminae are a good indicator of prehistoric occupation of the cave.

3) Radiocarbon AMS dating of organic fraction of black coloured laminae yielded calibrated ages falling between 6460 and 6640 years BP and 7160 and 7330 years BP.

4) The older date can be connected with human activity either of the later Gemer Linear Pottery or early (the earliest?) Bükk culture populations, while the younger one points to the youngest (IV) phase of the human occupation in Domica cave (Bükk culture phase C).

\section{ACKNOWLEDGEMENTS}

The authors wish to thank Zuzanna Banach for operating the SEM and Renata Jach for preparing the figures. Thanks are also due to Prof. Janusz Kozłowski and Doc. Marian Vizdal for their kind permission to quote radiocarbon date from site of Slavkovce. Constructive criticism of Marián Soják and an anonymous reviewer as well as editorial handling are kindly acknowledged. 


\section{REFERENCES}

Bárta J, 1965. Príspevok k pravekému osídleniu jaskýn Domickej Sústavy (Contribution to the prehistoric settlement of the caves of the Domica system). Slovenský Kras 5: 58-73 (in Slovak, English summary).

Bárta J, 1984. K otázke paleolitického umenia v slovenských jaskyniach (On the matter of Palaeolithic art in Slovak caves). Spravodaj Slovenskej Speleologickej Spoločnosti 25: 42-46 (in Slovak).

Bennington F, Melton C and Watson PJ, 1962. Carbon dating prehistoric soot from Salts Cave, Kentucky. American Antiquity 28: 238241.

Breuning P, 1987. ${ }^{14}$ C-Chronologie des Vorderasiatischen, Südost- und Mitteleuropäischen Neolithikums $\left({ }^{14} \mathrm{C}\right.$ Chronology of Near Eastern, South-East European, and Central European Neolithic). KölnWien, Böhlau: 247pp (in German).

Bronk Ramsey C, 1995. Radiocarbon Calibration and Analysis of Stratigraphy: The OxCal Program Radiocarbon 37(2): 425-430

Bronk Ramsey C, 2001. Development of the radiocarbon calibration program OxCal, Radiocarbon 43 (2A): 355-363

Clark JS, 1988. Particle motion and theory of charcoal analysis: source area, transport, deposition and sampling. Quaternary Research 30(1): 67-80, DOI 10.1016/0033-5894(88)90088-9.

Czernik J and Goslar T, 2001. Preparation of graphite targets in the Gliwice Radiocarbon Laboratory for $\mathrm{AMS}{ }^{14} \mathrm{C}$ dating. Radiocarbon 43: 283-291

Dravis JJ and Yurewicz DA, 1985. Enhanced carbonate petrography using fluorescence microscopy. Journal of Sedimentary Petrology 55(6): 795-804

Droppa A, 1970. Príspevok k vývoju jaskyne Domica (Contribution to the development of Domica Cave). Ceskoslovensky Kras 22: 65-72 (in Slovak, English summary).

Fezzey S and Armitage RA, 2006. Pyrolysis GC-MS and TGH-GC-MS studies of black coating from Little Lost River Cave, Idaho. Journal of Analytical and Applied Pyrolysis 77(2): 102-110, DOI 10.1016/j.jaap.2006.02.005

González LA, Carpenter SJ and Lohmann KC, 1992. Inorganic calcite morphology: roles of fluid chemistry and fluid flow. Journal of Sedimentary Petrology 62(3): 382-399.

Goslar T, Czernik J and Goslar E, 2004. Low-energy ${ }^{14} \mathrm{C}$ AMS in Poznań Radiocarbon Laboratory. Nuclear Instruments and Methods B 223-224: 5-11, DOI 10.1016/j.nimb.2004.04.005.

Gradziński M, Górny A, Pazdur A and Pazdur MF, 2003. Origin of black coloured laminae in speleothems from Cracow-Wielun Upland. Boreas 32(3): 532-542, DOI 10.1080/03009480310003414.

Gradziński M, Hercman H, Bella P, Debaene G and Nowicki T, 2002. Tmavé laminácie v sintrových nátekoch jaskyne Domica ako indikátor akivít pravekých l'udí (Dark coloured laminae within speleothems of the Domica Cave as an indicator of the prehistoric men activity). Slovenský Kras 40: 41-48 (in Slovak).

Hertelendi E and Horváth F, 1992. Radiocarbon chronology of Late Neolithic settlements in the Tisza-Marosz region, Hungary. Radiocarbon 34: 859-866.

Hertelendi E, Kalicz N, Raczky P, Horváth F, Veres M, Svingor E, Futó I and Bartosiewicz L, 1995. Re-evaluation of the Neolithic in eastern Hungary based on calibrated radiocarbon dates. Radiocarbon 37: 239-244.

Hertelendi E, Svingor E, Raczky P, Horváth F, Futó I and Bartosiewicz L, 1998. Duration of tell settlements at four prehistoric sites in Hungary, Radiocarbon 40: 659-665.

Hill CA, 1982. Origin of black deposits in caves. National Speleological Society Bulletin 44: 15-19.

Jones TP and Chaloner WG, 1991. Fossil charcoal, its recognition and paleoatmospheric significance. Paleogeography, Paleoclimatology, Paleoecology 97(1-2): 39-50, DOI 10.1016/00310182(91)90180-Y

Kalicz N and Makkay J, 1977. Die Linienbandkeramik in der Grossen Ungarischen Tiefebene. (Linearband Pottery of the Great Hungarian Plain), Budapest, Akadémiai Kiadó: 384pp (in German).

Lichardus J, 1968. Jaskyňa Domica: najvýznačnejšie sídlisko l’udu bukovohorskej kultúry (Domica Cave: the Most Important Site of Bükk Culture people). Bratislava, Vydavatel'stvo Slovenskej akadémie vied: 120pp (in Slovak, German summary).

Lichardus J, 1974. Studien zur Bükker Kultur (Studies in Bükk Culture). Saarbrücker Beiträge zur Altertumskunde 12. Bonn, Rudolf Habelt: 169pp (in German).
Patterson III WA, Edwards KJ and Maguire DJ, 1987. Microscopic charcoal as a fossil indicators of fire. Quaternary Science Reviews 6(1): 3-23, DOI 10.1016/0277-3791(87)90012-6.

Pavúk J and Šiška S, 1980. Neolit a eneolit (Neolithic and Eneolithic) In: Chropovský B, ed., K návrchu chronológie praveku a včasnej doby dejinnej na Slovensku (Towards the Synthesis of Chronology of Prehistory and Early History in Slovakia). Slovenská archeológia 28: 137-158 (in Slovak, German summary).

Petránek J and Pouba Z, 1951. Pokus o datování vývoje jaskynĕ Domice na základě studia tmavých zon v krápnících a sintru (Dating of the development of the Domica Cave, based on the study of the dark zones in the travertine formations). Sbornik Ústredniho Ústavu Geologického 18: 245-272 (in Czech, English summary)..

Raczky P, Meier-Arendt W, Anders A, Hajdú Z, Nagy E, Kurucz K, Domboróczki L, Sebök K, Sümegi P, Magyari E, Szántó Z, Gyulás S, Dobó K, Bácskay E, Birm K and Schwartz Ch, 2002. PolgárCsöszhalom (1989-2000): Summary of the Hungarian-German excavations on a Neolithic settlement in Eastern Hungary. In: Aslan R, Blum S, Kastl G, Schweitzer and Thumm D, eds., Mauerschau: Festschrift für Manfred Korfmann. Remshdalen-Grunbach, Bernhard Albert Greiner: 833-860.

Raczky P, Meier-Arendt W, Kurucz K, Hajdú Z and Sikora A, 1994. A Late Neolithic settlement in the upper Tisza region and its cultural connections (preliminary raport), A nyiregyházi Jósa András Múzeum Evkönyve 36: 231-241.

Reimer PJ, Baillie MGL, Bard E, Bayliss A, Beck JW, Bertrand C, Blackwell PG, Buck CE, Burr G, Cutler KB, Damon PE, Edwards RL, Fairbanks RG, Friedrich M, Guilderson TP, Hughen KA, Kromer B, McCormac FG, Manning S, Bronk Ramsey C, Reimer RW, Remmele S. Southon JR, Stuiver M, Talamo S, Taylor FW, van der Plicht $\mathrm{J}$ and Weyhenmeyer CE, 2004. IntCal04 terrestrial radiocarbon age calibration, 0-26 cal kyr BP, Radiocarbon 46:1029-1058.

Roth Z, 1948. Některé formy sintrové výzdoby v jeskyni Domica a jejich vznik. (Some speleothems from Domica cave and their origin) Sbornik Státneho Ústavu Geologického 15: 65-88 (in Czech, French summary).

Sander PM and Gee CT, 1990. Fossil charcoal: techniques and applications. Review of Paleobotany and Palynology 63(3-4): 269-279, DOI 10.1016/0034-6667(90)90104-Q.

Soják M, 2000. Neolitické osídlenie Spiša (Neolithic settlement of the Spiš). Slovenská archeológia 48: 185-314 (in Slovak, German summary)

Soják M, 2005. Osídlenie jaskýň (Human settlement in caves). In: Jákal J, ed., Jaskyne Svetového Dedičstva na Slovensku (World Heritage Caves in Slovakia). Liptovský Mikuláš: Správa Slovenských Jaskýň: 101-112 (in Slovak).

Steelman KL, Rowe MW, Boutton TW, Southon JR, Merrell CL and Hill RD, 2002. Stable isotope and radiocarbon analyses of black deposit associated with pictographs at Little Lost River Cave, Idaho. Journal of Archaeological Sciences 29(10): 1189-1198, DOI 10.1006/jasc.2001.0791

Šiška S, 1979. Die Bükker Kultur in der Ostslovakischen Tiefebene (The Bükk Culture in Eastern Slovakian Lowland). Slovenská archeológia 27: 245-287 (in German).

Šiška S, 1986. Anfänge der Polgár-Kultur in der Slowakei (The beginnings of the Polgár Culture in Slovakia). In: Internationales Symposium über die Lengyel-Kultur. Nové Vozokany 5.-9. November 1984. Nitra-Wien: Archäologisches Institut der Slowakischen Akademie der Wissenschaften, Institut für Ur- und Frühgeschichte der Universität Wien: 235-241 (in German).

Šiška S, 1989. Kultúra s východnou lineárnou keramikou na Slovensku (Eastern Linear Pottery Culture in Slovakia). Bratislava, Veda: 209pp. (in Slovak, German summary).

Šiška S, 1995. Zur Problematik des Untergangs der Bükker Kultur (The problem of the Bükk Culture decline). Slovenská archeológia 43 5-24 (in German).

Šiška S, 1998. Die Alföld-Linienbandkeramik und die Bükk-Kultur (The Alföld Linear Pottery and Bükk Culture). In: Preuß J., ed., Das Neolithikum in Mitteleuropa. Kulturen - Wirtschaft - Umwelt vom 6. bis 3. Jahrtausend v.u.Z. Übersichten zum Stand der Forschung, Band 1/2. Weissbach, Beier \& Beran: 268-273 (in German).

Teichmüller M and Wolf M, 1977. Application of fluorescence microscopy in coal petrology and oil exploration. Journal of Microscopy 109: 49-73. 
Titov V, 1980. Rannij i Sriednij Nieolit Wastocznoj Wiengrii (Early nad Middle Neolithic of Eastern Hangary). In: Titov V and Erdely I, eds., Arhieiologia Wiengrii: Kamiennyj Wiek. Moskwa, Nauka: 73-249 (in Russian).

Valladas H, Tisnérat-Laborde N, Cachier H, Amold M, Bernaldo de Quirós F, Cabrera-Valdés V, Clottes J, Courtin J, Fortea-Pérez JJ, González-Sainz C and Moure-Romanillo A, 2001. Radiocarbon AMS dates for paleolithic cave paintings. Radiocarbon 43: 977986.

Vaughan A and Nichols G, 1995. Controls on the deposition of char coal: implications for sedimentary accumulations of fusain. Journal of Sedimentary Research 65(1a): 129-135.

Vizdal M, 1998. K problematike neskoroneolitického vývoja na Východoslovenskej nížine (To the problematics of Late Neolithic in Eastern Slovak Lowland). Východoslovenský pravek 5: 91-104 (in Slovak).

Vogel JC and Waterbolk HT, 1964. Groningen Radiocarbon Dates V. Radiocarbon 6: 349-369.

Watson PJ, 1966. Prehistoric miners of Salt Cave, Kentucky. Archaeology 19: 237-243. 